\title{
Clinical Findings of Emergence After Olanzapine Overdosage: Pediatric Case Report and Review of Literature
}

\author{
Olanzapin Aşırı Alımı Sonrasında Ortaya Çıkan Klinik Bulgular: \\ Çocuk Olgu Sunumu ve Literatürün Gözden Geçirilmesi
}

\author{
Mehmet Dokur', Gülşen Pancar Gülmez'1, Samiye Uslu Kuzudişli² \\ 'Kilis State Hospital, Emergency Department, Kilis, Turkey \\ 2Zirve University EBN Medical Faculty, Department of Neurology \& Medical Education Gaziantep, Turkey
}

\section{ABSTRACT}

Introduction: Olanzapine is an atypical antipsychotic drug of the thienobenzodiazepine group; its clinical use has increased in the last 2 decades. Especially in pediatric cases, the clinical experience in overdose of olanzapine and other atypical antipsychotics is limited. Overdosage of atypical antipsychotic drugs, including olanzapine, predominately causes central nervous system depression and anticholinergic effects.

Case Report: We present the case report of a 3-year-old female child who ingested $20 \mathrm{mg}$ of olanzapine, which resulted in clinical findings, such as mental status changes, peripheral edema and rapid atrial rhythm, temporary prolonged P-R interval, and T-wave inversion.

Conclusion: According to the current literature, olanzapine seems to be a medium-level safe atypical antipsychotic drug in terms of clinical use. Therefore, the pediatric cases should be monitored closely with accidental olanzapine overdosage.

Keywords: Olanzapine, overdosage, pediatric case

Received: 23.04.2012 Accepted:04.09.2013

\section{ÖZET}

Giriş: Olanzapin, son iki dekattan beri kullanımı giderek artan tienobenzodizepin grubu bir atipik antipsikotik ilaçtır. Özellikle çocuk olgularda, olanzapin vediğer atipik antipsikotiklerin aşırı alımı ile ilgili klinik deneyimler oldukça sınırıdır. Olanzapinin de içinde olduğu atipik antipsikotiklerin aşıı alımı, başlıca santral sinir sistemi depresyonu ve antikolinerjik etkilere neden olur.

Olgu Sunumu: Biz, bu olgu sunumunda 3 yaşındaki bir kız çocuğunda $20 \mathrm{mg}$ olanzapin alımı sonrasında mental durum değişiklikleri, periferik ödem, hızlı atriyal ritim, geçici P-R mesafesi uzaması ve $T$ dalga inversiyonu gibi klinik bulguların görülebileceğini gösterdik.

Sonuç: Güncel literatüre bakıldığında, olanzapin klinik kullanım bakımından orta derecede güvenli bir atipik antipsikotik olarak görünmektedir. Bu yüzden kazaen aşırı dozda olanzapin alan çocuk olgular yakından monitorize edilmelidir.

Anahtar Kelimeler: Olanzapin, aşırı doz, pediyatrik olgu

Geliş Tarihi: 23.04.2012 Kabul Tarihi: 04.09.2013

\section{Introduction}

Having been marketed for almost 17 years as an atypical antipsychotic drug, olanzapine is a new atypical antipsychotic drug that has become widespread in prescriptions day by day. Olanzapine is used for the treatment of psychoses, schizophrenia, schizoaffective disorders, bipolar disorders, and other conditions with psychotic or delusional components (1). Presumably, as the usage of these medications in adults increases, the frequency of unintentional pediatric ingestions will increase.

Evidence on the efficacy and safety of atypical antipsychotics in children and adolescents with schizophrenia is limited. The use of typical antipsychotics has been limited to patients who are resistant to atypical antipsychotics and intolerant to their 
adverse effects or require injections or depot preparations. Besides, further double-blind, placebo-controlled trials and long-term safety assessments are needed before definitive conclusions can be reached about the place of atypical antipsychotics in the therapeutic armamentarium of childhood-onset schizophrenia (2).

Olanzapine affects dopaminergic (D1-4), serotonergic (5HT2, 5HT3, 5HT6), histaminergic (H1), muscarinic (M1-5), and adrenergic (a1) receptors. The metabolism of olanzapine is complex; it is primarily metabolized by the cytochrome P-450 system (CYP-450), mostly by the isoenzyme 1A2 system and 2D6. Olanzapine can also cause an increase of serum transaminase levels during medications (3).

Although structurally and functionally related to clozapine, olanzapine possesses a more favorable side effect profile. Although the usual dose range for olanzapine is $5-15 \mathrm{mg} / \mathrm{d}$, there are no standard reference values with respect to the expected concentrations of olanzapine after therapeutic administration. In clinical studies, steady-state blood (plasma) concentrations of olanzapine are rarely over $150 \mathrm{ng} / \mathrm{mL}$, but the potential for toxicity has been suggested at concentrations as low as $100 \mathrm{ng} / \mathrm{mL}$. Generally, new atypical antipsychotic drugs may have a safer therapeutic, side effect, and overdose profile than firstgeneration antipsychotic drugs. Olanzapine has slight side effects on the extrapyramidal system (EPS) in low dosage intake (4). Olanzapine overdoses in children are generally associated with more significant adverse effects. With another statement, the symptoms in overdose are generally a reflection of olanzapine's known pharmacological actions and encompass somnolence, mydriasis, blurred vision, respiratory depression, hypotension, and extrapyramidal and anticholinergic effects.

Children who are potentially ingesting a toxic dose or who are symptomatic should be considered for

assessment in a hospital. Children, therefore, require more active intervention than adults. Furthermore, they should be monitored closely when ingestion of olanzapine occurs. Most cases resolve with good supportive care (5).

\section{Case Report}

A 3-year-old girl was brought to our emergency department on account of accidental digestion of medicine containing olanzapine (Rexapin ${ }^{\circledR}$ ) (20-mg tablets; Abdi Ibrahim Medical, Istanbul, Turkey), which is used by her mother.

In the physical examination arrival, the vital parameters were determined as: blood pressure relatively low (systolic $=90 \mathrm{~mm} \mathrm{Hg}$ and diastolic $=50 \mathrm{~mm} \mathrm{Hg}$ ), tachycardic (151 bpm), body temperature was normal

$\left(36.5^{\circ} \mathrm{C}\right)$, respiratory rate: $22 / \mathrm{min}$, and $\mathrm{spO}_{2}: 95 \%$. Weight was 15 $\mathrm{kg}$ (percentile of range 50\%-75\%). She was conscious but had a somnolence status with insufficient cooperation. Glasgow Coma Scale $(G K S)=10-12$. Other system examinations were normal. On the arrival ECG, rapid atrial rhythm was determined after drug intake at the $90^{\text {th }}$ minute (Figure 1). Laboratory examination findings on arrival were: WBC: $7.9 \mathrm{~K} / \mu \mathrm{L}, \mathrm{Hgb}: 14.7 \mathrm{~g} / \mathrm{dL}, \mathrm{PLT}$ : $360 \mathrm{~K} / \mu \mathrm{L}$; glucose: $126 \mathrm{mg} / \mathrm{dL}$, BUN: $20 \mathrm{mg} / \mathrm{dL}$, creatinine: $0.4 \mathrm{mg} / \mathrm{dL}, \mathrm{AST}: 71 \mathrm{U} / \mathrm{L}, \mathrm{ALT}$ : $101 \mathrm{U} / \mathrm{L}, \mathrm{LDH}: 227 \mathrm{U} / \mathrm{L}, \mathrm{CK}: 81 \mathrm{U} / \mathrm{L}, \mathrm{Na}: 145 \mathrm{mmol} / \mathrm{L}, \mathrm{K}: 4.7 \mathrm{mmol} / \mathrm{L}$, Cl:9 8mmol/L, and Ca: $9.4 \mathrm{mg} / \mathrm{dL}$.

After the first physical examination in the emergency department, gastric lavage, activated charcoal (1 g/kg), intravenous fluids, and oxygen (2-3 L/min.) were rapidly applied, and the child case was monitored in supportive care. In this case, treatment in accordance with the symptoms that might occur was planned. On arrival, for the hypotension and tachycardia, $1500 \mathrm{cc}$ ringer lactate was applied (for the first 24 hours) as intravenous fluid. In the following days, she was given approximately $1000 \mathrm{cc}$ ringer lactate as intravenous fluid every 24 hours. No medication applications were needed. At the 5th hour of observation, sinus rhythm and prolonged P-R interval were determined as $103 \mathrm{bpm}$ after drug intake at the 5th hour (Figure 2), and blood pressure was slightly low (systolic=95 $\mathrm{mm} \mathrm{Hg}$ and diastolic $=55 \mathrm{~mm} \mathrm{Hg}$ ), GCS= 12, and Poisson Severity Score (PSS)=2. However, at the 7th hour of observation, a slight level of sinus tachycardia (117 bpm) and additionally supraventricular premature complexes and T-wave negativities in anterior derivations occurred. Meanwhile, ongoing slightly prolonged P-R interval was determined (Figure 3). After the first night and throughout the entire observation, it was determined that $\mathrm{GCS}=15$. On the 4th day of observation, supraventricular tachycardia (SVT) was monitored, but the slightly prolonged P-R interval recovered itself (Figure 4). On the 10th day, electrocardiogram (ECG) findings were abnormal, except the rapid atrial rhythm recovered (Figure 5). Therefore, on the14th day, the ECG findings recovered exactly.

The laboratory findings were recorded at the 5th and 8th hours of patient monitoring: AST: $64 \mathrm{U} / \mathrm{L}$ and $72 \mathrm{U} / \mathrm{L}, \mathrm{ALT}: 91 \mathrm{U} / \mathrm{L}$ and $98 \mathrm{U} / \mathrm{L}$, and LDH: $183 \mathrm{U} / \mathrm{L}$ and $192 \mathrm{U} / \mathrm{L}$. CK value progressed at the normal

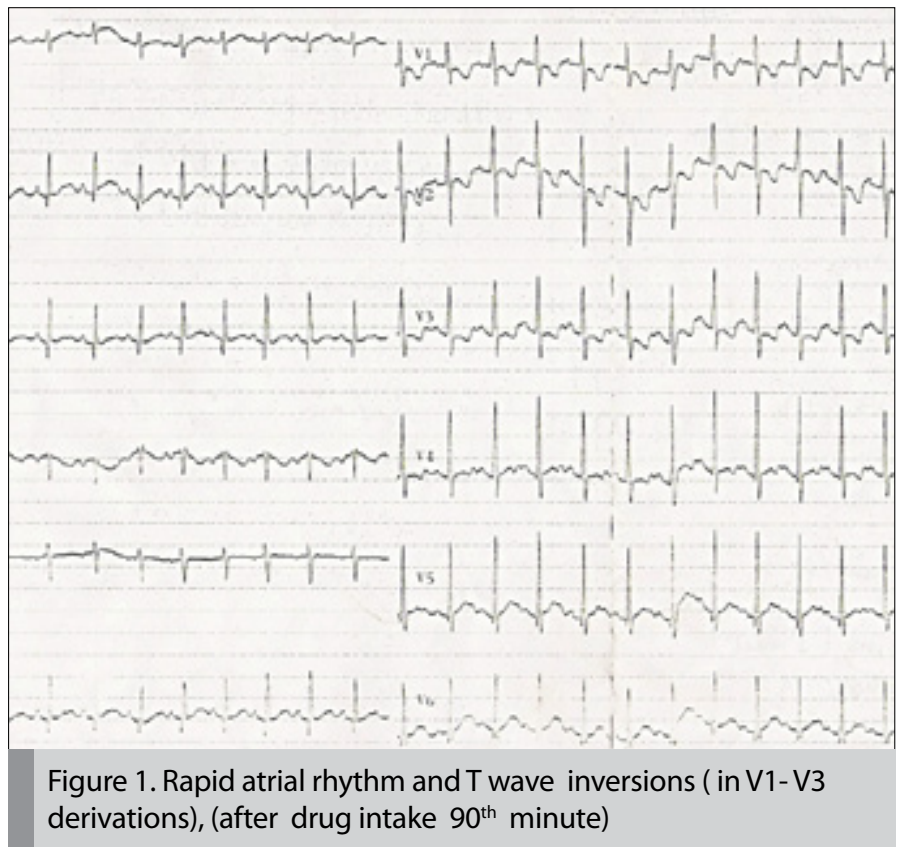




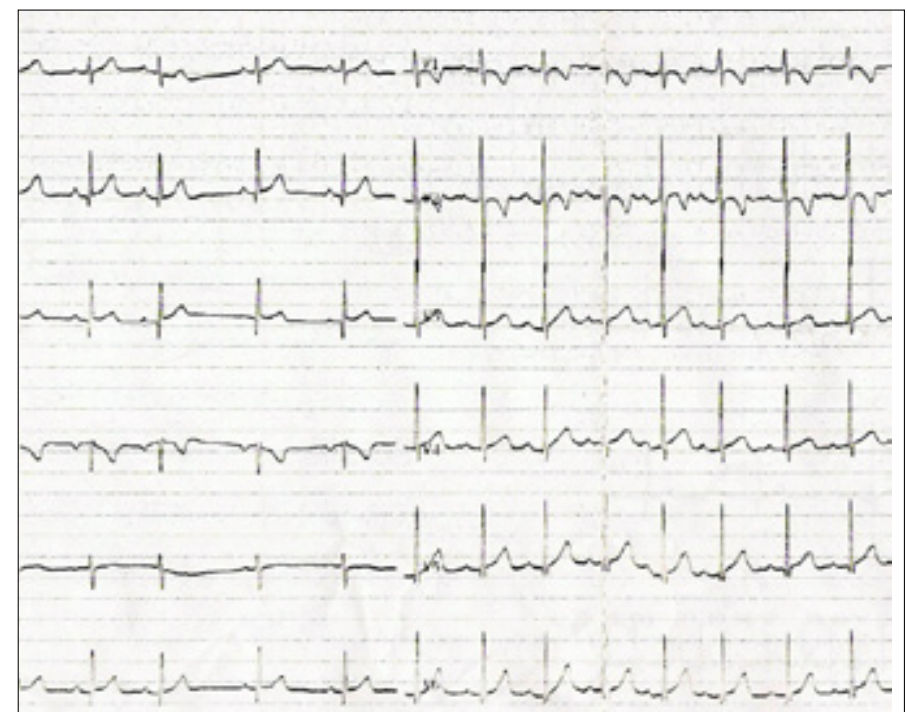

Figure 2. Slightly prolonged P-R interval and ongoing T wave inversions (after drug intake $5^{\text {th }}$ hour)

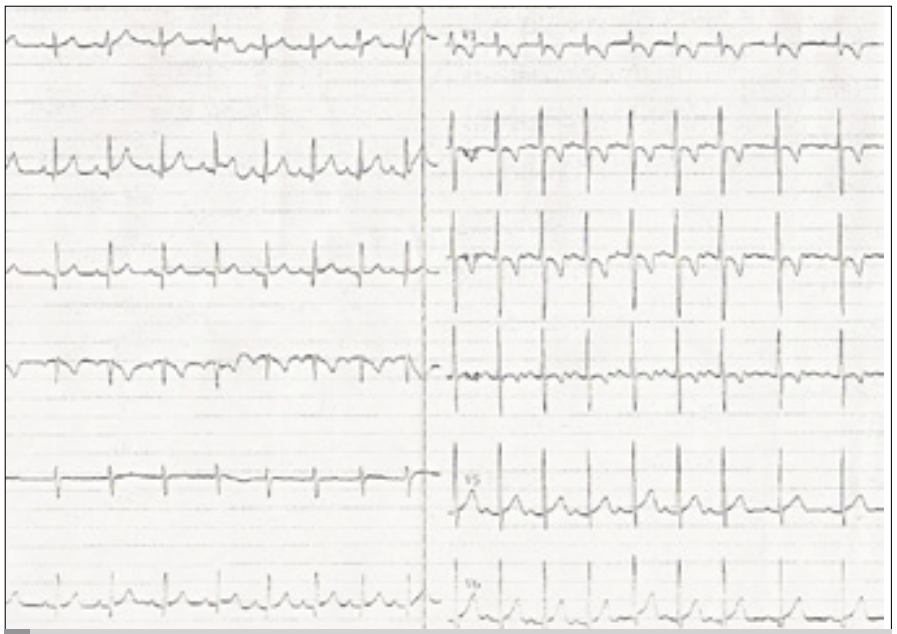

Figure 3. Ongoing T-wave inversions(in V1-V4 derivations) and slightly prolonged P-R interval (after drug intake at 7th hour)

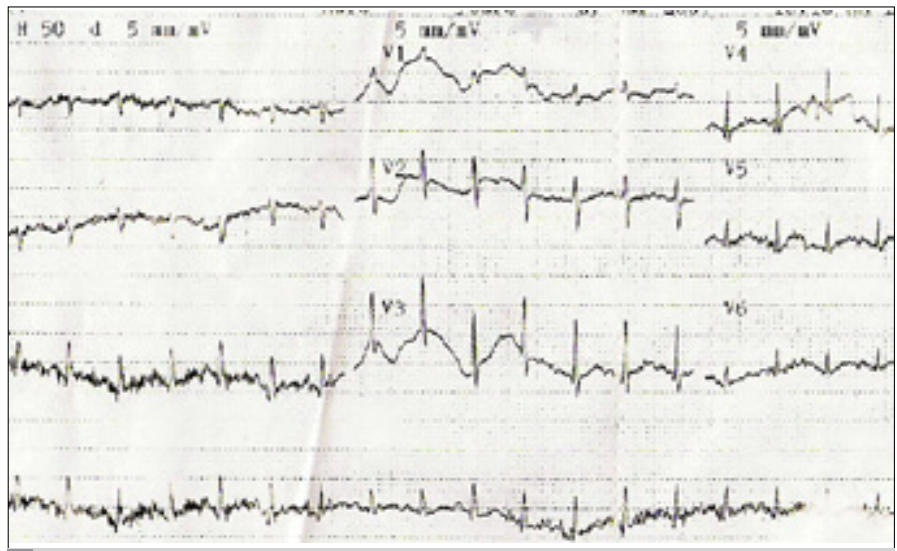

Rapid atrial rhythm (SVT) and recovered slightly prolonged P-R interval (after drug intake $4^{\text {th }}$ day)

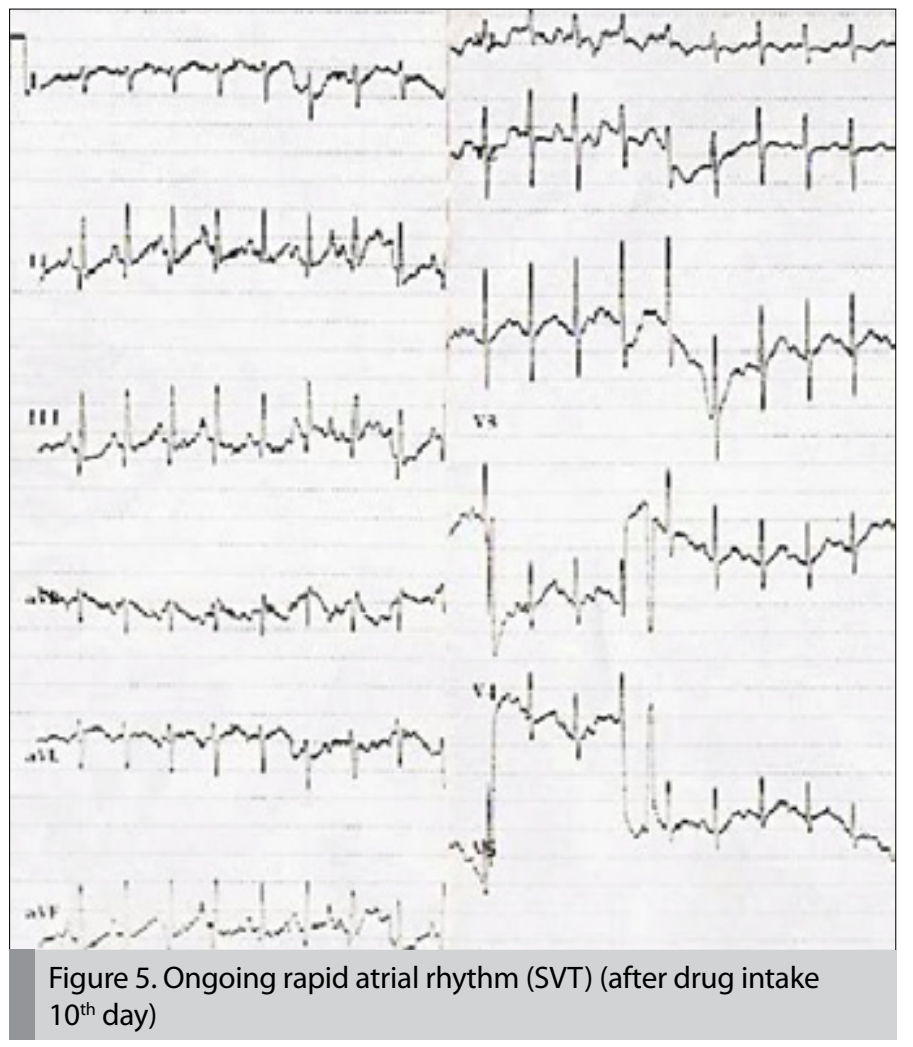

limits. Among the electrolytes, the level of sodium decreased down to $135 \mathrm{mmol} / \mathrm{L}$ on the first day of observation and $133 \mathrm{mmol} / \mathrm{L}$ on the 7th day of observation despite the electrolytic liquid replacement. Slightly hyponatremic findings were accompanied with edema in the hands, face, and feet. As of the 7th day of observation, AST and ALT values turned back to normal rates, and the LDH levels could hardly return to normal values as of the 10th day. As of the 10th day of observation, the hyponatremia and edema recovered. Throughout the monitoring duration, hypotension progressing in the case was not accompanied with any other hemodynamic disorders and findings of EPS. Furthermore, no respiratory distress occurred.

The case was externed on the 7th day of observation on the condition that she would be called for controls.

\section{Discussion}

Although the side effect profile and toxidrome of atypical antipsychotic drugs in adults are well known, their overdosage information in pediatric age groups is rather new and limited.

Recently, atypical antipsychotic agents have largely replaced traditional agents as first-line drugs for the treatment of schizophrenia and psychotic mood disorders. Considering the increase in atypical antipsychotics prescriptions and the increased risk of suicide in this patient population, the number of reported cases of antipsychotic drugs may be expected to increase. Olanzapine has been considered to be similar to clozapine, but olanzapine intoxication appears to have a relatively benign clinical course as compared with clozapine intoxication. In olanzapine intoxications, deep coma, myosis, and 
mild cardiovascular effects were observed (6).

According to Newcomer, the results of studies regarding secondgeneration (atypical) antipsychotics and metabolic effects are relevant to primary and secondary prevention efforts that aim to address the multiple factors that contribute to the increased prevalence of type 2 diabetes mellitus and cardiovascular disease in populations that are often treated with second-generation antipsychotic medications (7). Komossa et al. pointed out that olanzapine may be a somewhat more efficacious drug than some other second-generation antipsychotic drugs. This small superiority in efficacy needs to be weighed against a larger weight gain and associated metabolic problems than most other second-generation antipsychotic drugs, except clozapine. They suggested that further large, well-designed trials are necessary to establish the relative effects of different second-generation antipsychotic drugs.

Intoxication cases related with olanzapine are expected to increase day by day where olanzapine becomes a commonly prescribed antipsychotic medicine. In home child accidents, among 1-4-yearold children, intoxication with cleaning materials and drugs left around are encountered more frequently. The intake of olanzapine in the age range of 0-6 only occurs accidentally (5). The age and the way of intoxication of our case are in compliance with this fact. Especially in pediatric cases, the clinical experience in overdose of olanzapine and other atypical antipsychotics is limited. Research has demonstrated that the toxic dose for olanzapine is $0.5 \mathrm{mg} / \mathrm{kg}$ (enough to cause central nervous system depression). Unintentional antipsychotic ingestion in children can cause severe effects that last 1-3 days, often with one tablet.

Olanzapine's multireceptor action (antagonism to dopaminergic D1, D2, D4; serotoninergic 5-HT2A, 5-HT2C; histaminergic H1; cholinergic M1-5; and a1pha-adrenergic receptors) results in multiple clinical symptoms in the course of acute poisoning. In the course of acute olanzapine poisoning, the prevailing symptoms come from the circulatory and central nervous systems; some symptoms are mutually opposed, such as coma-psychomotor agitation, hypertension-hypotension, tachycardia-bradycardia, hyperthermiahypothermia, and miosis-mydriasis. Rarely, consciousness disturbances may persist for up to 6 days after olanzapine overdose; the course of poisoning can be severe, sometimes complicated, but fatal outcomes are rare. Koçer et al. (8) reported an adult case that developed diabetes insipidus following massive olanzapine ingestion and returned to normal after desmopressin treatment.

Overdose results in significant symptoms, including respiratory distress and mental status changes in infants. Catalano et al. (5) presented the case of an 18-month-old boy who ingested 30-40 mg of olanzapine, which resulted in significant symptoms, including respiratory distress and mental status changes. They stressed that previously reported pediatric cases of olanzapine ingestion have described similar symptoms. According to Catalano et al., the pediatric population should be monitored closely when ingestions of olanzapine occur. In another study, Catalano et al. suggested that special care may be warranted with all pediatric cases of atypical antipsychotic overdose, including monitoring in a high-intensity clinical setting to manage potential respiratory or cardiac difficulties. Broyd pointed out in her study that although there are several reports of olanzapine mimicking opiate intoxication in overdoses, this is one of the first cases where overdose has mimicked an intracerebral event. According Broyd, the authors highlight some of the literature regarding clinical presentation and treatment options and discuss the relation between olanzapine therapy and diabetes. Duration of overdose symptoms ranged from 24 hours to 7 days. In the literature, a case of olanzapine overdose in which symptoms resolved in 13 days was recorded. Our case was beyond the low boundary of toxic doses and was in compliance with overdose symptoms for olanzapine.

Reviewing the publications concerning overdosage of olanzapine, atypical antipsychotic drugs, including olanzapine, predominately have central nervous system depression and anticholinergic effects. In addition, opioid-like presentations and extrapyramidal manifestations in small children have been reported. The clinical presentations include drowsiness, lethargy, agitation, irritability, combativeness, fluctuating mental status, and tachycardia without arrhythmia (rapid atrial rhythm) that occurs within 2 hours after ingestion (5). Kochlar et al. reported a case of an olanzapine overdose in a 12-year-old boy. In this case, an opioidlike presentation was noted. Moreover, despite a high serum level of olanzapine, the patient made a complete recovery and showed no sequelae at the follow-up (9). Similarly, O'Malley et al. pointed out that olanzapine should be added to opioid and alpha (2)-adrenergic agonist intoxication in the differential diagnosis of the patient with depressed mental status and miosis. Lankheet et al. demonstrated relatively mild symptoms after olanzapine intoxication in a 2-yearold girl with excessively high serum levels.

Steil reported a case of delirium due to olanzapine overdose. After ingestion of $280 \mathrm{mg}$ of olanzapine, a 19-year-old schizophrenic patient developed delirium with consciousness disturbance; disorientation in time, space, and situation; acoustic and visual hallucinations; and agitation. In this case, there were no abnormalities in the ECG, EEG, or routine blood tests. Approximately $36 \mathrm{~h}$ after the intoxication, the patient recovered fully. Furthermore, Steil pointed out that until now, there have been no reports of delirium from this cause. Theisen et al. reported on two cases of adolescents who attempted suicide with an overdose of olanzapine. A 14-yearold female ingested $275 \mathrm{mg}$ olanzapine that caused somnolence, agitation (acutely), and EPS (after 54 hours) but no major clinical complications. A 17-year-old male ingested 400 mg olanzapine, which produced respiratory suppression requiring intubation and mechanical ventilation; he recovered after 3 days. Based on clinical monitoring and postmortem data, the two patients survived the ingestion of high doses of olanzapine. Morgan et al., in their study, described the spectrum of clinical effects in olanzapine overdose and investigated the factors that predict severe outcomes in adult patients. They analyzed olanzapine overdose events confirmed by drug analysis. In this study, demographic, clinical, and outcome 
data were recorded for each presentation, and olanzapine overdose caused a high rate of delirium and central nervous system sedation that required significant resources. Morgan et al. suggested that olanzapine overdoses should be initially observed for 6 h; on the other hand, patients not taking olanzapine regularly may have more severe effects.

The initial findings of our case, such as lethargy emerging after the digestion of drug, may be based on the opiate-like effect of olanzapine. The hypotension and tachycardia observed in our case seem to be based on the a-adrenergic receptor occupancy property of olanzapine. In these cases, serum olanzapine level, weight of the patient, coingestants, the health of the patient at baseline, relevant laboratory and toxicology studies, and a standardized scale to rate the level of consciousness, such as the Glasgow Coma Scale (GCS) and the Poisoning Severity Score (PSS), should be assessed. On admission, in our case, GCS was slightly low (GKS=12). Furthermore, clinically, agitation and drowsiness were seen somewhat.

The most frequently employed treatments include intubation, gastric lavage, activated charcoal, intravenous fluids, artificial respiration, and restraints or sedatives. It is a more convenient approach to apply gastric lavage up to 2 hours later and generate absorbents effect by activated charcoal up to 6-8 hours later than digestion of medicine in cases of intoxication of medicine. In our case, we thought that applying gastric lavage 7 hours later after digestion would still be effective with respect to the probable anticholinergic effect of olanzapine. As the hypotension did not cause hemodynamic disorder in our case, crystalloid liquid replacement was decided to be sufficient, as sympathomimetic agent usage was not needed. However, throughout the observation, temporary rhythm disorders and T wave alterations that emerged in ECG of the case might imply arrhythmogenic and cardiotoxic effects of olanzapine. Tan et al. found 13 pediatric cases ( $<7$ yr), 22 adolescent cases (7-16 years), and 185 adult cases. No pediatric case described a ventricular dysrhythmia or a cardiovascular death. In the adolescent and adult cases, we found numerous reports of prolonged QTc interval and hypotension, but there were only three cases of ventricular dysrhythmia and three deaths that may have been due, to direct cardiovascular toxicity. The results from case series reports were similar to the single case report data. Their findings suggested that overdose of atypical antipsychotics is unlikely to cause significant cardiovascular toxicity. However, further research about this subject is needed. Heart rhythm alterations showed the necessity of close cardiovascular observation in cases as well.

Ballesteros et al., in their study, reported an acute olanzapine monointoxication with severe toxicity and high whole-blood olanzapine concentrations. They pointed out that clinical and analytical data of similar samples obtained in non-fatal life-threatening cases can be very useful when interpreting postmortem cases.

Olanzapine is an atypical antipsychotic with multireceptor affinity and different pharmacological effects, which can result in abnormalities in laboratory investigations. In acute olanzapine poisoning, muscle and liver injury, serum glucose and electrolyte abnormalities, and changes in complete blood count (CBC) can be present; the valuable parameters for the monitoring of the course of poisonings are: serum activity of creatine phosphokinase (CPK) and transaminases (alanine transaminase: AST, alanine transaminase: $A L T)$, serum level of bilirubin, glucose, potassium, and sodium and CBC. Hyperprolactinemia probably lacks practical importance, but further investigations are needed in this area. Waring et al. reviewed case notes from 64 consecutive patients admitted to their own institution after olanzapine overdose. They demonstrated overall and serum CK that was higher than 5 times the upper limit of normal in $17 \%$ of patients. According to this study, the prevalence of raised creatine kinase (CK) values was positively correlated with the stated quantity of olanzapine ingested, suggesting a dosedependent relationship for acute muscle toxicity, and despite the high prevalence of acute muscle toxicity after olanzapine ingestion, none of the patients developed renal failure. In our case, serum CK levels were normal. No acute muscle toxicity after olanzapine ingestion was found. This state may be related to lower-dose olanzapine ingestion.

In our case, the high levels of AST and ALT determined 7 hours later then digestion of drug were related with conjugation and oxidation of olanzapine in liver (1). It might indicate that the elimination half-life of olanzapine in babies is a bit longer, and the lactate dehydrogenase (LDH) enzyme plays a part in the metabolism of medicine, as the AST and ALT levels could hardly return back to normal values after the 7th day and LDH levels could hardly return back to normal values after the 10th day of observation. The accompaniment of slight hyponatremia to edema beginning on the 3rd day of observation and the simultaneous recovery of both diseases might imply that hyponatremia is an edema-causing side effect of olanzapine. Further research about this subject is needed. Throughout the monitoring duration, the accompanying of hemodynamic disorders with hypotension, findings of EPS, or respiratory distress did not occur, as we interpreted them to be relevant to lower dose intake of olanzapine. Except for the extreme overdose cases, emerging clinical findings are considerably reversible; yet, close monitoring is recommended. Rare fatal pediatric cases have been recorded, as well $(3,10)$. Lennestal et al. reported that in their study's series of serum concentrations, a two-phase elimination was seen, with an initial elimination half-life of about $24 \mathrm{~h}$ during the first 3 days, followed by a second phase with a half-life of about 2.5 days. The patient in this case recovered completely. Because the elimination time after intoxication can be considerably longer than expected, it is recommended that the patient's serum concentrations after intoxication be monitored.

In a multicenter study, the annual reports of the American Association of Poison Control Centers National Data Collection System were reviewed from 1990 to 2003, the most recent report currently available. All fatalities in children and youths under 18 years of age were included. In this study, the literature review identified 40 reports that included 63 patients, ranging in age from 1 day to 17 years of age. The clinical presentations included drowsiness, 
lethargy, agitation, irritability, combativeness, and tachycardia. There were 11 fatalities in the cases reviewed: 1 from clozapine overdose, 3 from risperidone overdose, 2 from olanzapine overdose, and 5 from quetiapine overdose. All other cases reported no significant sequelae and resolved without any reported clinical consequences. Duration of overdose symptoms ranged from 24 hours to 7 days. One case of clozapine intoxication showed resolution of symptoms in 6 hours, and in another case of olanzapine overdose, symptoms resolved in 13 days. This study suggested that it is a need for future case reports to include serum medication level, weight of the patient, coingestants, the health of the patient at baseline, relevant laboratory and toxicology studies, and a standardized scale to rate the level of consciousness, such as the GCC. On the other hand, the existing pharmacovigilance data reports indicate that these medications are relatively safe when taken in overdose, particularly when coingestants are not involved (2).

Cobaugh et al. prepared a guideline to assist poison center personnel in the appropriate out-of-hospital triage and out-ofhospital management of patients with suspected acute ingestions of atypical antipsychotic medications by describing the process by which an ingestion of an atypical antipsychotic medication might be evaluated, identifying the key decision elements in managing cases of atypical antipsychotic medication ingestion, providing clear and practical recommendations that reflect the current state of knowledge, and identifying needs for research.

Balicka et al. presented a retrospective analysis of the clinical course of eight acute olanzapine intoxications treated at the Department of Clinical Toxicology, Jagiellonian University Medical College. In this study, central nervous system (CNS) symptoms, manifested as fluctuations between somnolence/coma and agitation/ aggression and miosis, were observed in most of the patients. Moreover, increased CPK activity was stated in the most of patients. Consequently, all of the patients recovered, and poisoning severity according to PSS was moderate and severe (10). In our case, PSS was moderate $(P S S=2)$. This state may be related to lower-dose olanzapine ingestion.

Chue and Singer examined the available data on olanzapine in untreated overdose situations. They point out that olanzapine is associated with toxicity in certain overdose situations, but evidence of any relation is limited and likely influenced by the higher rates of cardiovascular disease and sudden death in subjects with schizophrenia. This study suggested that similar toxicity data reviews should be conducted for all commonly prescribed psychotropics. In addition, early signal detection and effective notification processes are crucial in the event that serious adverse effects do occur.

Komossa et al. pointed out olanzapine may be a somewhat more efficacious drug than some other second-generation antipsychotic drugs. This small superiority in efficacy needs to be weighed against a larger weight gain and associated metabolic problems than most other second-generation antipsychotic drugs, except clozapine. They also suggested that further large, well-designed trials are necessary to establish the relative effects of different secondgeneration antipsychotic drugs.

Although olanzapine is tolerated relatively well in acute overdose, unpredictable and transient fluctuations between central nervous system depression and agitation, frequently associated with miosis, appear to be characteristic findings in moderate to high olanzapine overdoses. They are transient in nature and require careful clinical monitoring but rarely require specific therapeutic interventions.

\section{Conclusion}

Having side effects on the central nervous system, cardiovascular system, and metabolism, olanzapine can threaten lives, depending on dosage, especially accidental digestion cases in children. Parents should consider that not only olanzapine but also all other medications left around means danger for children. Therefore, it is important to inform families sufficiently about this subject with respect to preventive medicine. This case is important in terms of olanzapine to take its cardiac effects in pediatric cases, even in lowdosage digestions. Olanzapine seems to be a medium-level safe medicine in terms of overdosage.

Hasta Onamı: Yazılı hasta onamı hastanın ailesinden alınmıştır.

Hakem Değerlendirmesi: Dış bağımsız.

Yazar Katkıları: Fikir - G.G.P.; Tasarım - M.D; Denetleme - M.D; Malzemeler - G.G.P.; Veri toplanması ve/veya işlemesi - G.G.P.; Analiz ve/veya yorum - M.D.; Literatür taraması - M.D.; Yazıyı yazan - G.G.P; Eleştirel İnceleme- S.U.K.

Çıkar Çatışması: Yazarlar çıkar çatışması bildirmemişlerdir.

Finansal Destek: Yazarlar bu çalışma için finansal destek almadıklarını beyan etmişlerdir.

Informed Consent: Written informed consent was taken from the patient's parents.

Peer review: Externally peer-reviewed.

Author Contributions: Concept - G.G.P.; Design - M.D; Supervision - M.D; Materials - G.G.P.; Data Collection and/or Processing - G.G.P.; Analysis and/or Interpretation - M.D; Literature Review - M.D; Writer - G.G.P.; Critical Review - S.U.K.

Conflict of Interest: The authors declared no conflict of interest.

Financial Disclosure: The authors declared that this study has received no financial support.

\section{References}

1. Sattar SP, Gastfriend DR. Olanzapine-induced hyperventilation: case report. J Psychiatry Neurosci 2002; 27: 360-3.

2. Toren P, Ratner S, Laor N, Weizman A. Benefit-risk assessment of atypical antipsychotics in the treatment of schizophrenia and comorbid disorders in children and adolescents. Drug Saf 2004; 27: 1135-56. [CrossRef] 
3. Evren C. Olanzapine: A new atypical antipsyhotic drug. Bull Clin Psychopharmacol 1998; 8: 74-80.

4. Leucht S, Pitschel-Walz G, Abraham D, Kissling W. Efficacy and extrapyramidal side effects of the new antipsychotics olanzapine, quetiapine, respiridone and sertindole compared to conventional antipsychotics and placebo. A meta-analysis of randomized controlled trials. Schizophr Res 1999; 35: 51-68. [CrossRef]

5. Catalano G, Cooper DS, Catalano MCet al. Olanzapine overdose in an 18-month-old child. J Child Adolesc Psychopharmacol 1999; 9: 267-71. [CrossRef]

6. Magdalan J, Wasyko-Smolarek M, Antończyk A, Kochman K, Przewłocki M, Porebska B.Intoxications with atypical antipsychotic drugs--data of the Acute Intoxication Unit in Wrocław. Przegl Lek 2004; 61: 392-6.

7. Newcomer JW. Second-generation (atypical) antipsychotics and metabolic effects: a comprehensive literature review. CNS Drugs 2005; 19 Suppl 1: 1-93. [CrossRef]

8. Koçer E, Alçelik A, Canan F.Olanzapine intoxication-related transient diabetes insipidus. Ren Fail 2011; 33: 842-3. [CrossRef]

9. Kochhar S, Nwokike JN, Jankowitz B, Sholevar EH, Abed T, Baron DA. Olanzapine overdose: a pediatric case report. J Child Adolesc Psychopharmacol 2002; 12: 351-3. [CrossRef]

10. Balicka-Slusarczyk B, Szczeklik J, Szpak D, Groszek B. Clinical course of acute poisoning with olanzapine. Przegl Lek 2005; 62: 489-91. 